\title{
Headteachers' Perspectives About the English Language Teaching at Lower Secondary Level in Shaheed Benazirabad, Pakistan
}

\author{
Naseem Hyder Rajput* \\ M.Phil. Associate, Department of Education, Shaheed Benazir Bhutto University, Shaheed Benazirabad, \\ Pakistan \\ Muhammad Yaseen Chandio \\ M.Phil. Associate, Department, of Education, Shaheed Benazir Bhutto University, Shaheed Benazirabad, \\ Pakistan \\ Rafique Nawaz Bhutto \\ M.Phil. Associate, Department of Education, Shaheed Benazir Bhutto University, Shaheed Benazirabad, \\ Pakistan \\ Zahid Hussain Kanhio \\ M.Phil. Associate, Department of Education, Shaheed Benazir Bhutto University, Shaheed Benazirabad, \\ Pakistan
}

\begin{abstract}
English is a global language that enjoys a unique status of lingua franca all over the world. English is the compulsory part of the curriculum up to graduation level in Pakistan. Yet the quality of the English language is very poor in Pakistan. This study described the perspectives of male headteachers of public lower secondary schools about Methods of English language teaching and expertise of English language teachers. A qualitative descriptive approach was used to describe these perspectives. The population consisted of 25 male headteachers of the public sector lower secondary schools of Taluka Sakrand. The Study reached out to 20 headteachers through purposive sampling. The data were collected using semi-structured interviews. The collected data were analyzed using thematic analysis. The results of the study suggest that methods of teaching used are defective as they do not improve the listening and speaking skills of the students. The teachers are inexperienced in second language pedagogy as neither they hold an academic degree in English nor they are trained in second language pedagogy. It is recommended that English language teachers should be given pieces of training in second language pedagogy so that they can apply modern methods for teaching English.
\end{abstract}

Keywords: English Language, Headteachers, Perspectives, Lower secondary Level

DOI: $10.7176 /$ JLLL/71-04

Publication date:August $31^{\text {st }} 2020$

\section{Introduction}

"English is not a language which can be taught; it is a language which must be learnt." (Michel West).

In Pakistan, people involved in imparting education are not satisfied with present state of English language teaching (Hussain, 2011); English teaching is neither satisfactory nor favorable for learning of the language (Warsi, 2004). In Sindh, English plays an important part. It is a common resource of official communication-along with Urdu and other local languages. it is an established fact that after study of English at school and college levels for a period of six or eight years the students are still unable to converse easily and fluently. This case is even more severe with the students coming from rural backgrounds and rural districts like Shaheed Benazirabad. Students are very much short of all the four main skills of linguistics which are reading, writing, listening and speaking (Alam \& Bashiruddin, 2013). As the acquisition of English is a skill, therefore it should be treated in that direction. It is also very much evident that the traditional methods of English teaching used in Sindh have not provided the preferred results of proficiency in English communication. Grammatical patterns are the basis of English language teaching in Sindh; language teaching trend is just bookish and casual. The focus of the students is just on the reading and writing to produce sentences. My argument is that people involved in English language teaching, directly or indirectly, like educators, researchers of second language acquisition \& the teachers of the English language must treat it from the perception of usage. They should try to improve the conditions under which English is being taught in both urban and rural regions of Sindh.

The course of overseas language teaching comprises selection, marking and presentation as key measures (Umar \& Majeed, 2018). Ellis (2005) argued that if learners are not exposed to the language being taught, they will not be able to acquire the language being taught. It means that the learning of the language being taught is directly proportional to the exposure the learner receives. So, it is advisable to increase the usage of the target language inside the classroom. Preferably, this means that target language should be treated both as a medium and 
objective of the instruction. Best \& Tyler (2007) explained the significance of exposure to target language \& it is definite that successful acquiring of second language occurs through exposure to the target language. Fillmore \& Snow (2000) argue that there is a crucial liaison between native \& second languages. Nation (2003) elucidated that if a teacher finds that a meaning of a task based on target language is beyond the learning capacities of the learners, s/he can introduce small discussions in native language to get rid of the hurdle.

Educational demography of Sindh Province of Pakistan is very exclusive that requires a detailed analysis regarding the formulation of the language policy. According to the Annual School Census 2009-10, the medium of instruction in $87 \%$ of the public schools in Sindh is Sindhi with $7.9 \%$ of the schools having Urdu medium, and only $0.3 \%$ of the schools are English medium and $4.6 \%$ of the schools fall in the category of mixed schools. These figures highlight the obstacles that might be faced by transitioning to an English mode of teaching. Despite various steps taken by the government of Sindh to improve the conditions of English language teaching no improvement has taken place in this regard. Headteachers are the actual observers of real English teaching. It is important to know what Headteachers of the schools think about the problems of poor English teaching conditions. This study has been undertaken to fill this gap by describing headteachers' perspectives about methods of teaching used for teaching English language and expertise of English language teachers in the teaching of English language in Taluka Sakrand of Shaheed Benazirabad.

Theoretical explanations of the problems of English language teaching can help in the understanding of various factors that lead to poor conditions of the English language teaching. There are many theoretical perspectives about how the second language is learned: Behaviorism; Structuralism; Interactionism; Constructivism, Learning Motivation; Comprehension Hypothesis; Basic Interpersonal Communicative Skills and Cognitive Academic Language Proficiency; English Textbooks in Use for Language Learners; Caring, Supportive Teachers that Matter; Testing and Assessment that Play a Role in Students' Academic Success (Rao, 2018). Among these, three main theorists (Behaviorists, Innatists, and Interactionists) portray different perspectives about the language learning. Ultimately these strongly influence the methods of language learning and teaching. Behaviorists only believe in three things in language learning; stimuli, responses, and reinforcements. They do not give importance to the cognitive processes involved in language learning. The Innatists believe that the main domains of language learning are Universal Grammar and Language Acquisition Devices. There is no role of environment in language learning in Innatism. According to Interactionists, interaction is of prime importance for ensuring prosperous language learning but it overlooks other important prerequisite factors that are very important for language development. As no single model is sufficient to accommodate for all the problematic language learning factors so the roots of this study have been driven from combined Behaviorist, Innatists and Interactionist model (Nor \& Ab Rashid, 2018).

\subsection{Research Questions}

1. What are the headteachers' perspectives about methods of teaching used for the teaching of the English language?

2. What are the headteachers' perspectives about the expertise of English language teachers in teaching the English language?

\section{Methodology}

\subsection{Research Design}

By method research design of this study is qualitative and by purpose descriptive. The researcher attempted to describe the perspectives of headteachers about Methods of English language teaching and the expertise of English language teachers. To collect the qualitative data from the participants semi-structured interviews were conducted.

\subsection{Population and sample}

The population consisted of 25 male headteachers of public lower secondary schools of Taluka Sakrand. The headteachers were selected as samples because they are the regular observers of the teaching process of English language. Data saturation was used to determine the sample size. The Study reached out to 20 Headteachers through purposive sampling. 
2.3 Demographic information

Table 1. Summary of demographic information

\begin{tabular}{|c|c|c|c|c|c|c|c|}
\hline $\begin{array}{c}\text { No. of } \\
\text { Interviewees }\end{array}$ & Gender & $\begin{array}{c}\text { Average } \\
\text { Age } \\
\text { (Years) }\end{array}$ & $\begin{array}{c}\text { Academic } \\
\text { Qualification }\end{array}$ & $\begin{array}{l}\text { Professional } \\
\text { Qualification }\end{array}$ & $\begin{array}{c}\text { Teaching } \\
\text { Experience } \\
\text { (years) }\end{array}$ & $\begin{array}{l}\text { School } \\
\text { Level }\end{array}$ & $\begin{array}{l}\text { School } \\
\text { Type }\end{array}$ \\
\hline 20 & $\begin{array}{c}\text { All } \\
\text { Male }\end{array}$ & 51 & $\begin{array}{l}\text { Masters in } \\
\text { Political } \\
\text { Science (07) } \\
\text { Masters in } \\
\text { Economics } \\
\text { (04) } \\
\text { Masters in } \\
\text { Sindhi (04) } \\
\text { Masters in } \\
\text { Urdu (03) } \\
\text { Masters in } \\
\text { English (02) }\end{array}$ & $\begin{array}{l}\text { All Masters } \\
\text { in Education }\end{array}$ & 30 & $\begin{array}{l}\text { Lower } \\
\text { Secondary }\end{array}$ & Boys \\
\hline
\end{tabular}

According to the data presented in table 1, seven interviewees were holding Master's level academic degrees in Political Science, four in Economics, four in Sindhi; a local language, three in Urdu; a local language and two in English. All the interviewees were holding Master's level professional degrees in Education. The average age of the interviewees was fifty-one years while the average experience was thirty years. All the Interviewees were supervising lower secondary level Boys Schools.

\subsection{Data Collection}

Data was collected from the 20 male Headteachers of public lower secondary schools. For collecting the data, the researcher went to the selected schools and formally obtained the permission from the headteachers. The researchers collected the data through semi-structured interviews. The duration of each interview was between 45 minutes and one hour. The researchers used cell phones to record the interviews. The researcher transcribed the cell recorded interviews and shared them with interviewees for review. Once the approval of the transcript was granted, the interviews proceeded for thematic analysis.

\subsection{Data Analysis}

The process used to identify themes within qualitative data that you have collected is called thematic analysis. The thematic analysis has the primary objectives of identifying themes that are important or interesting and use these to address your research. The major advantage of employing a thematic analysis process from the aspect of teaching and learning is that it is a method rather than methodology (Clarke \& Braun, 2013). Because of this advantage, it is not bound to any theoretical or epistemological perspective. This unique advantage makes it a very flexible method especially in the context of diversity found in the work of teaching and learning. It is because of this advantage the thematic analysis process was used to analyze the collected qualitative data.

After becoming familiar with the data and generating initial codes a thorough search was carried out to identify the themes. This was followed by the reviewing of identified themes so that these can be modified and developed to check whether they make any sense? The last step was defining the identified themes in which, the reviewed themes were refined to identify the essence of each theme.

\section{Results and Discussion}

3.2 RQ1. What are the headteachers' perspectives about methods of teaching used for the teaching of the English language?

3.2.1. Theme 1: Defective Methods of Teaching

The majority $(95 \%)$ of the participants were of the view that the methods used by the language teachers are defective. These results are consistent with previous researches (e.g., Warsi,2004; Akram \& Mehmood, 2007; Muhammad, 2003; Amur, Butt, \& Malik, 2015), in those all agreed on the defectiveness of this old and obsolete method. The results further add to these studies by describing the problematic teaching activities performed by the English language teachers. These activities augment the defectiveness of the teaching methods:

In my school the first word of all the English teachers to students after greetings is "read the

lesson" and consequently, the students start the reading of the English lesson. The last activity

of the students in class is noting down something from the whiteboards. (interviewee, 5).

It means that the proceedings of almost all the English language classes start with "reading activity" and end with "writing activity." This results in the improvement of only reading and writing skills of English. It makes no improvement in speaking and listening skills. As Haider (2012) illuminated that language is not chiefly learned 
through replication, the outdated translation technique is still used by the majority of English teachers. 3.2.2. Theme 2: Use of Grammar Translation Method is burdensome and problematic

All the interviewees indicated that their English teachers used the Grammar translation Method; these results support the previous results of (Awan \& Hiraj,2016; Mohammad, Masum, \& Baksh, 2018); in those, all found that all the teachers use old and obsolete Grammar Translation Method. The Present study's results further add to the results of previous studies by highlighting the burdensome nature of this method in mixed category classrooms. The preference to use the grammar-translation method is because teachers favor teaching in the mother tongue through which students demonstrate better learning and understanding (Gopang et al,2017); it's also convenient, time-saving, and suitable for overcrowded classrooms (Awan \& Hiraj,2016). They take the help of the first language to teach English. This method of teaching from English to first languages is burdensome for the teachers. Teachers teach English through Grammar and memorizing of the meaning of new words in Urdu and Sindhi languages:

One of the daily teaching activities of my teachers is to listen to new words meaning and teach English grammar in the Sindhi language. (interviewee, 7).

This extra workload aggravates in mixed category schools where the teachers have to translate English both in Sindhi and Urdu languages. This results in an extra amount of workload on teachers as all the teachers are not competent in both the local languages; some teachers are competent in Sindhi only, some in Urdu only and only a few in both. Only reading and writing skills are improved by this procedure but it does not bring any improvement in the listening and speaking skills of the students. Rules of Grammar and meaning of the new words are also explained in the mother tongue. This method is faulty because like any other language English is also about speaking and listening. Wilson (2000) argued that the grammar-translation method provides little opportunity for language acquisition. According to Wilson (2000), acquiring any language neither necessitates widespread use of grammar rules nor does it occur overnight. The acquisition of any language is a slow and gradual process.

3.2.3. Theme 3: The majority of communication between teachers and students is in local languages with teachers talking most of the time

All the interviewees revealed that their teachers of English spent the majority of teaching making students writing and reading aloud. There is no teacher to student and vice versa conversation in English; these results support the results of (Mohammad, Masum, \& Baksh, 2018), in which authors had highlighted that the English is taught in a manner similar to the teaching of other subjects, such as Pakistan Studies and General Science. These subjects are in local languages, so teachers carry the teaching manners of these subjects and apply them to English teaching. All the communication is in local languages. Even greetings at the start of the class are not in English. This is resulting in poor communication skills of the students (Alam \& Bashir Uddin, 2013). In the word of interviewee, 17:

I have never seen any of my school's students communicating with his English language teacher in English. The most of the talking time is taken by the teacher and in local languages. The students talk very less of the time. (interview, 20).

Previous researches suggest that there should be a balance between teacher and students talk time in the class. To improve interaction skills, the teachers' talk time should be reduced, and the students should be given even more time (Hall, 2017). This increased talk time given to the students will increase the opportunities of talking and practicing.

3.2.4. Theme 4: Teachers are unaware of the latest research in second language pedagogy

Data analysis suggests that $75 \%$ of the respondents were of the view that the teachers of the English language even do not know the names of modern English language teaching methods:

Once I asked an English teacher of my school who was teaching to students of class eight for thirty years that which method do you apply in class for teaching English? The reply was I make students read the lesson, write dictation, explain the meaning of difficult words and explain the rule of grammar if one needs explanation. (Interviewee, 3)

This indicates that the teachers of the English language are not keeping themselves up to date with the latest research in second language pedagogy. They even do not know the names of methods that can be used for teaching English. They even do not know the name of the method that he uses despite the fact he holds a Master's Degree in Education. They just know the activities that they make their students perform in class. 3.2.5. Theme 5: Teachers focus on just transfer of knowledge but not on usage of English

Results of the study also indicated that over $90 \%$ of the respondents were of the view that in their schools almost all the English language teachers focus on mainly just completion of their English coursebook within the stipulated time:

My English language teachers spend most of their time in classes making the students completing the exercises of the lessons without giving any importance to the fact whether or not students are comprehending the text of the lessons. (interviewee, 12)

This indicated that teaching methods used by most of the English language teachers are mainly examinations 
oriented. Teachers are preparing students for the sake of success in the examinations. No attention is granted to the real learning that is taking place within the students. This results in just the transfer of knowledge. Teachers are not focusing on language usage skills that are an essential part of any language learning. Students are not provided the opportunity in the class to practice English language skills.

As a regular examination system does not offer any importance to listening and speaking skills so these language teaching practices do not provide a strong foundation for speaking skills of the students in the coming years of lives. Students just become crammers of language. Because of this week foundation, even after studying English language up to graduation level students are not able to express simply their thoughts in the English language.

\subsection{RQ2. What are the headteachers' perspectives about the expertise of English language teachers in teaching} the English language?

3.3.1. Theme 1: Teachers are inexperienced in second language pedagogy

The interviews demonstrated that $75 \%$ of the respondents were of the view that the English language teachers do not possess expertise that is needed to teach the English language. These results support the results of Bashiruddin \& Qayyum (2014); in most cases, the teachers cannot be regarded as competent English teachers in the absence of relevant academic qualifications.

The interviewees also indicated that the teachers are also not satisfied with their English teaching skills; they believed they did not have adequate English proficiency for teaching the English language. These results support the previous research of Channa (2014), in which he found the discontent of English teachers with their English teaching skills and proficiency. In the words of interviewee, 17:

I have English language teachers who are only experienced in terms of time spent in teaching English. They have been teaching the English language to various classes for twenty-five years but had never undergone any training or specialized courses in second language pedagogy. (interviewee, 11)

Courses and comprehensive pieces of training in second language pedagogy are of great importance in teaching English (Koning et al., 2016; Channa,2014). In the absence of effective professional pieces of training and courses, the English teachers are unable to transform their classrooms into efficient foreign language learning classrooms. They are producing good quality products for the examination of the English language. When these products reach the local competitive market of English speaking in the coming years, they prove to be a failure. In that competitive market, they had to compete with those peers who come from good standard private schools (Siddiqui \& Gorard, 2017). This failure is the result of the unskillful learning that they had undergone in early years of education.

3.3.2. Theme 2: Professional trainings are not arranged by the government

Recently the government of Sindh has changed the textbooks from class sixth to eighth. All the interviewees expressed that none of their teachers was given training about the changes made in those textbooks. All the interviewees also expressed that not a single teacher of the English language had received any training in second language pedagogy in the last twelve years. Neither any such training was organized by the government nor had the teachers approached at their own. As a result, most teachers were not capable of keeping themselves up to date of progressive research in second language pedagogy. This has resulted in the improper implementation of changed textbooks as teachers are the ultimate interpreters of the curriculum (Ireland, O'Sullivan, \& Duchesne, 2017).

3.3.3. Theme 3: Teachers are neither academically qualified nor willing to teach English

More than half of the interviewees were of the view that there is a dearth of academically qualified English language teachers. These teachers also are not academically and professionally qualified in teaching the English language. These results reaffirm the results of Bahiruddin and Qayyum (2014); English teachers are not academically qualified. Teachers who were teaching the English language were not holding any specialized degrees or training courses:

As I have no teacher who has a degree in English so degree holders in other languages like

Economics, Political Science, Sindhi, Urdu, etc. have been teaching the English language to various classes for years. (interviewee, 19)

The interviews indicated that in schools where language specialist teachers of English were available, unfortunately, they were not willing to teach the language of English; rather, they were more inclined to teaching other languages like local language. This disinclination of the public sector English language teachers is strikingly different than English language teachers of private schools who are self-motivated to teach English (Bahiruddin \& Qayyum, 2014).

The interviewees also revealed that in some special cases where luckily the teacher is holding a degree in English and teaching the English language was very poor at the pronunciation of English because ultimately s/he was the product of the same system to which s/he is leading now. Even those who possess a master's degree in English has never gone to university. They possess a non-regular degree. 


\section{Conclusion}

This study described the perspectives of Headteachers of Lower Secondary Public Schools of Pakistan about methods used for English teaching and expertise of English language teachers. According to them the methods used for English teaching are defective. These methods are examination-oriented and mainly improve reading and writing skills. These do not improve the listening and speaking skills of the students. This results in good reading and writing skills but poor listening and speaking skills of the students. Learning the English language requires practicing to improve communication. In Pakistani classrooms, students are not provided enough time to communicate in the English language as most of the communication from teacher to student and vice versa is in local languages. Teachers focus is just on transfer of knowledge and no opportunity is provided for usage.

The teachers are only experienced in terms of time spent in teaching English. They are not experienced in second language pedagogy. They do not possess any specialized degrees and courses in English. They had not undergone any professional training in English teaching. Their academic qualifications are not in English. Even after spending years in English teaching they still do not know the even names of modern teaching methods of English.

The English language teachers are required to develop professionally so that they can become competent in English language teaching. They are required to abandon defective teaching methods and undergo some professional pieces of training in second language pedagogy. The results of this study can be inspiring for the teachers for their professional development.

The major limitation of this study is that it did not describe the perspectives of female Headteachers of lower secondary level public schools due to social constraints. The description of their perspectives would be profitable for further validation of this research.

\section{Recommendations}

\subsection{Training of Teachers}

As one is required to go to a medicinal college \& study how the human lungs work to appreciate lung's problems \& carry out operations. So is the case with the teaching of English. Teachers of the English language should be aware of modern methods of second language teaching. Whenever any change is made in the curriculum, the teachers should be trained accordingly. Teachers should also be provided refresher courses to keep their knowledge and methodologies up-to-date.

\subsection{Abandoning the Classical Translation Method}

Content-based Instruction (CBI) has to be included in teaching English in rustic and city areas (Warsi, 2004). Language is educated through social communications is the base of this argument (Cook, 2016). Therefore, if students are permitted to express their opinions in English about relevant societal, political and financial problems, then it is sensible to presume that they will master the needed abilities particularly listening and speaking, with comparative easiness and achievement (Bryman, 2016). Activities of the class should be child-centered, and teachers should use only English to communicate with the students. Students should also be encouraged to incorporate English in their everyday lives; not only at school but also at their homes. The method of teaching should be communicative and the homework given to the students should also be such that it focuses on creativity and communication. At least 15 minutes watching any program in English should also be part of homework. Disposing of the classical translation method and employing modern teaching methods like direct teaching method will also decrease the workload of the teachers in mixed category classes which will ultimately increase the performance of English language teachers. The students' English learning will also be improved as students will be exposed to longer periods in the English language class.

\section{Limitations}

No description of the perspectives of female headteachers make the scope of this study limited. Interpretation of the results of this study should be made cautiously.

\section{References}

Akram, M., \& Mahmood, A. (2007). The status and teaching of English in Pakistan. Language in India, 7(12), 17.

Alam, Q., \& Bashir Uddin, A. (2013). Improving English oral communication skills of Pakistani public school's students. International journal of English language teaching, 1(2), 17-36.

Amur, A., Butt, F. A., \& Malik, I. (2015). Problems of teaching English in government colleges of district Khairpur Mirs Sindh Pakistan. International Journal of Research in Social Sciences, 5(1), 328-347.

Awan, A. G., \& Hiraj, A. A. (2016). Teaching English as a Second Language in Pakistan at secondary level. Science international, 28(4).

Bashiruddin, A., \& Qayyum, R. (2014). Teachers of English in Pakistan: Profile and recommendations. NUML 
Journal of Critical Inquiry, 12(1), 1-19.

Best, C. T., \& Tyler, M. D. (2007). Nonnative and second-language speech perception: Commonalities and complementarities. Language experience in second language speech learning: In honor of James Emil Flege, $1334,1-47$.

Bryman, A. (2016). Social research methods. Oxford university press.

Channa, L. A. (2014). English medium for the government primary schools of Sindh, Pakistan: An exploration of government primary school teachers' attitudes (Unpublished doctoral dissertation). Athens, GA: University of Georgia.

Clarke, V. \& Braun, V. (2013) Teaching thematic analysis: Overcoming challenges and developing strategies for effective learning. The Psychologist, 26(2), 120-123.

Cook, V. (2016). Second language learning and language teaching. Routledge.

Education and Literacy Department, Government of Sindh. (2010). Statistical Bulletin Annual School Census 2009-2010. Retrieved from: http://www.rsu sindh.gov.pk/semis/Profile201112/Statistical\%20Bulletin\%202009-10.pdf

Ellis, R. (2005). Principles of instructed language learning. System, 33(2), 209-224. https://doi.org/10.1016/j.system.2004.12.006

Fillmore, L. W., \& Snow, C. E. (2000). What teachers need to know about language?

Gopang, A. S., Panhwar, A. H., Chachar, A. A., \& Nizamani, H. A. (2017). Issue of Language as The Medium of Instruction in Pakistan: An Analytical Study. The Shield-Research Journal of Physical Education \& Sports Science., 11.

Hall, G. (2017). Exploring English language teaching: Language in action. Routledge.

Hussain, M. A. (2011). Relationship of classroom environment with anxiety and attitude of secondary school students towards the learning of English (Doctoral dissertation, International Islamic University Islamabad). http://prr.hec.gov.pk/jspui/handle/123456789/2006

Ireland, J., O'Sullivan, K. A., \& Duchesne, S. (2017). English Syllabus interpretation: The relationship between literary theories and teacher beliefs. English in Australia, 52(2), 55.

König, J., Lammerding, S., Nold, G., Rohde, A., Strauß, S., \& Tachtsoglou, S. (2016). Teachers' professional knowledge for teaching English as a foreign language: Assessing the outcomes of teacher education. Journal of Teacher Education, 67(4), 320-337. https://doi.org/10.1177\%2F0022487116644956

Mohammad, N., Masum, R., Ali, Z., \& Baksh, K. (2018). Teaching practices of English language in the schools of Lasbela District, Pakistan. International Journal of Experiential Learning \& Case Studies, 2(2), 34-39.

Muhammad, S. (2013). Second language reading instruction in Pakistan. Procedia-Social and Behavioral Sciences, 70, 1403-1412.Nation, P. (2003). The role of the first language in foreign language learning. Asian EFL Journal, 5(2), 1-8. doi: 10.1016/j.sbspro.2013.01.204

Nor, N. M., \& Ab Rashid, R. (2018). A review of theoretical perspectives on language learning and acquisition. Kasetsart Journal of Social Sciences, 39(1), 161-167. https://doi.org/10.1016/j.kjss.2017.12.012

Rao, X. (2018). Learning Theories that Impact English Teaching and Learning. In University English for Academic Purposes in China (pp. 21-39). Springer, Singapore.

Siddiqui, N., \& Gorard, S. (2017). Comparing government and private schools in Pakistan: The way forward for universal education. International Journal of Educational Research, 82, 159-169.

Umar, A. T., \& Majeed, A. (2018). The Impact of Assessment for Learning on Students' Achievement in English for Specific Purposes: A Case Study of Pre-Medical Students at Khartoum University: Sudan. English Language Teaching, 11(2), 15-25.

Warsi, J. (2004). Conditions under which English is taught in Pakistan: An applied linguistic perspective. Sarid Journal, 1(1), 1-9.

Wilson, R. (2000). A summary of Stephen Krashen's' Principles and practice in second language acquisition'. 2008-10-15]. http://www. Language impact.com/articles/rw/krashenbk. htm. 